\title{
TARPKULTŪRINĖS KOMPETENCIJOS ASPEKTAI: NEVERBALINĖS KOMUNIKACIJOS REIKŠMĖ MOKYMOSI PROCESE
}

\author{
Lina Nikitinaite \\ Mykolo Romerio universitetas \\ Ateities g. 20, LT-08303 Vilnius, Lietuva \\ Elektroninis paštas: linanil88@gmail.com
}

Pateikta: 2017 m. kovo 17d.; priimta spausdinti 2017m. rugsëjo $12 \mathrm{~d}$.

DOI: DOI:10.13165/SMS-17-9-1-06

Santrauka. Šiame straipsnyje nagrinèjama neverbalinè komunikacija mokymosi procese kaip vienas iš tarpkultūrinès kompetencijos aspektu, nes neverbaline kompetencija lydi ir papildo verbalinę komunikacija bei atskleidžia tikrąsias mokymosi proceso dalyvių emocijas ir mintis. Bendravimas yra svarbiausias procesas, kuris dominuoja visose gyvenimo situacijose, ypač bendraujant su tarpkultürinèmis studentu grupèmis, bet dažnai pamirštama, kad jame svarbūs ne tik žodžiai, bet ir kūnas, jo kalba. Todèl ignoruojant neverbalinę komunikacija, praleidžiamas pro akis didžiausias srautas informacijos. Norint to išvengti, verta mokèti küno kalba bei jos aspektus, nes tik tada, supratus ir skyrus didesnį dèmesį neverbalinei komunikacijai, pagerètu mokymosi proceso efektyvumas.

Reikšminiai žodžiai: neverbalinė komunikacija, kūno kalba, mokymosi procesas, tarpkultūrinè kompetencija.

Atlikti tyrimai atskleide, kad tik 7\% žodinès ir rašytinės informacijos (verbalinė komunikacija) priimama mokymosi proceso metu, visa kita informacija, t. y. $93 \%$ gaunami neverbaline komunikacija (Pease, 2003: 13). Neverbalinė komunikacija yra tokia svarbi, jog kūno ignoravimas mokymosi procese reikštų ignoruoti visą organizmą - jis yra vientisas organų rinkinys ir jo funkcijos turi didelę reikšmę mokymuisi. Nepakankamas 
dèmesys suaugusiụjų švietejjų ir besimokančiųjų emocijoms, kurios lemia aplinkos sukūrimą bei medžiagos prieinamumą ir įsisavinimą, yra šio tyrimo problema. Dėmesys neverbalinès komunikacijos svarbai švietime skiriamas per mažas, todẻl iškyla klausimas, ar neverbalinė komunikacija turi reikšmės mokymosi procesui?

Šio straipsnio objektas - neverbalinè komunikacija mokymosi procese.

Straipsnio tikslas - nustatyti neverbalinės komunikacijos reikšmę mokymosi procese.

Tyrimo metodas. Tyrimas atliktas naudojant anketinę apklausą. Imtis - proginė, nereprezentatyvi, netikimybinè. Tyrimo dalyviai - 31 respondentas, besimokantis ịvairiose švietimo institucijose, daugiausia aukštosiose mokyklose, ịvairiose studijų pakopose. Besimokančiųų amžius yra 18-30 metų. Tarp jų 27 moterys ir 4 vyrai.

Neverbalinės komunikacijos samprata ir teorinis pagrindas. Terminų „kūno kalba“ ir "neverbalinè komunikacija“ reikšmès yra miglotos. Oksfordo anglų kalbos žodyne (2005) pateiktas apibrèžimas, jog „kūno kalba - tai sąmoningi ir nesąmoningi kūno judesiai ar kūno padètis, per kuriuos mes išreiškiame savo požiūrị ir jausmus." Oksfordo verslo anglų kalbos žodynas (2009) siūlo šiek tiek kitokị apibrěžimą. Tinkamai žodyne pabrèžiama prasmè, kad kūno kalba gali būti panaudota kaip įrankis, nors tai gali būti nevalingas poelgis be jokio tikslo: „kūno kalba - tai vienas iš bendravimo procesų, kurio pagalba jūs parodote, ką jaučiate ar galvojate ir tai jūs parodote padedant kūnui, o ne žodžiams." Kiti žodynai kūno kalbai suteikia kitą reikšmę - kinestetiką, t. y. neverbalinės kalbos interpretacija. Tai vienas iš būdų studijuoti tam tikrus kūno judesius ir gestus kaip nežodinès komunikacijos formą.

Tam tikri neverbaliniai signalai yra universalūs visiems žmonėms, tačiau skiriasi įvairiose kultūrose. Pavyzdžiui, žmonèms būdingos tam tikros universalios veido išraiškos: liūdesys, laimė, pyktis, nepasitikèjimas, nustebimas, baimè (Cooper ir kt. 2007: 54), tačiau kultūra apsprendžia, kada šias emocijas rodyti / nerodyti, kur bendraudamas žmogus turi stovèti ir kokiu atstumu, ką galima liesti, seka gestikuliavimo laiką ir dažnumą, akių kontakto palaikymą arba žiūrèjimą i šoną, kada garsiai ar tyliai kalbèti, kada juoktis ar susiraukti ir pan. Tai, jog neverbalinis ir verbalinis bendravimas papildo ar pakeičia vienas kitą, yra universalu visose kultūrose, tačiau kaip ir kada tai yra išreiškiama, ịvairiose kultūrose skiriasi. Todèl svarbu išmanyti neverbalinę kalbą, nes ji pasako daugiau nei žodžiai (Matulienè 2007: 78).

Rejus Birdwhistellis yra vienas iš svarbiausių teoretikų ir tyrinètojų kinestetikos srityje, kurioje jis tyrinejjo daugiau nei trisdešimt metų ir buvo vadinamas kinestetikos tèvu (Ekman, 2003: 23). Jis savo darbams naudojo lingvistikos modeli.

Ewardas Hallas yra proksemikos tèvas. Proksemika nagrinèja, kaip gyvūnai ir žmonès naudoja erdvę, esančią aplink. İ savo erdvę ịsileidžiame artimą žmogų, o nuo mums nepatinkančio laikomès per atstumą. Nustatyti keturi nuotoliai: intymus - nuo prisilietimo iki $45 \mathrm{~cm}$; asmeninis - nuo 45 iki $122 \mathrm{~cm}$; socialinis - nuo 122 iki $366 \mathrm{~cm}$; viešasis - daugiau negu $366 \mathrm{~cm}$ (Hall, 1963: 87).

Trečioji neverbalinès komunikacijos kategorija būtų parakalba arba balso tembro bendraujant reikšmè (Ekman, 2003: 23). Tai yra sąveika tarp verbalinès ir neverbalinès komunikacijos. Garsai, kuriuos mes išskiriame bendraudami, susiję tiesiogiai su kalba, bet nèra kalbos komponentas. Tragerio darbai šioje srityje nèra labai gerai žinomi, kaip 
kitų autorių, bet tai yra labai didelis įnašas mūsų supratimui. Targeris paralingvistiką dalina ị keturis tipus: kalbos tempa - tai balso aukštumas, artikuliacija ir ritmas; balso tonas apima tokius garsus kaip juokimasis, verkimas, žiovavimas ir pan; balso intonacija charakterizuoja manierą, kuria žmogus pasako žodžius ir frazes; tembras apima kalbos ritmą, tai yra tokie žodeliai kaip „uh“, „um“, pauzès ir kiti balso pertraukimai.

Apibendrinant turimas žinias apie neverbalinę komunikaciją ar kūno kalbą, galima pabrěžti, jog neverbalinẻ komunikacija dominuoja visur ir visada, yra traktuojama kaip savaime suprantamas reiškinys, tačiau turi didelę itaką bendravimo procesui bei yra tiek universali, tiek skirtinga įvairiose kultūrose.

Neverbalinės komunikacijos reikšmė mokymosi procese. Suaugusiems mokantis svarbu ne tik išgirsti, bet ir pamatyti, kaip yra perduodama informacija. Tai yra vienas iš būdų, kai geriau ịsimenama medžiaga, nes prisimenama, su kokia veido išraiška suaugusiųjų mokytojas pasakojo, kokie buvo jo gestai, kokias emocijas perteikè. Šiuo atveju neverbalinè kalba mūsų bendravime tampa ne mažiau reikšminga už verbalinę: ji padeda geriau išreikšti norimas mintis: „bežodè komunikacija yra keitimasis daiktine, veiksmine informacija; gestais, mimika, pantomimika, jausmų išraiška ir t. t. Tačiau šią informaciją reikia mokèti teisingai šifruoti, kad būtų išvengta klaidų." (Jovaiša 1993: 66). Anot A. Bierach (2000: 20), „Žmogui kalba duota tam, kad jis galètų nuslèpti savo mintis. Tačiau tai, ką jis nori nuslèpti kalbėdamas, dažniausiai išduoda kūnu“.

Stebėdamas besimokančiųjų tarpusavio bendravimą, iš kūno kalbos dèstytojas gali pasakyti, ką besimokantieji mąsto, kokias emocijas išgyvena. Aiškiausiai emocijos matomos veide. Gebejimas veidu išreikšti stiprias emocijas ji pagyvina, leidžia be žodžių išreikšti mintị. Tiesa ir tai, kad veido išraiška greitai kinta, nes kūno kalboje atsispindi emocijos, kurias žmogus jaučia konkrečios situacijos metu. Jeigu gerai pažinsime veido išraišką, tai jos kitimas leis suprasti, kaip keičiasi pašnekovo nuotaika bendravimo procese. Mokymosi procese dèstytojas, stebėdamas besimokančiųjų išraišką, supranta, ar dèstoma medžiaga ịdomi, aiški, suprantama. Tokiu atveju galima keisti situaciją, pateikti klausimus, kad besimokantieji išreikštų savo mintis, ir pareikštų, ką jau žino tam tikru klausimu. Tada mokymosi procesas tampa efektyvesnis.

Neverbalinẻ komunikacija suaugusiųjų mokymosi procese. Atliekant tyrimą buvo siekta išsiaiškinti neverbalinès komunikacijos svarbą suaugusiųjų mokymosi procese. Anketa sudaryta iš uždarų ir atvirų klausimų. Imtis - proginè, nereprezentatyvi, netikimybinè - ị imtį buvo įtraukiami prienami populiacijos elementai, 31 ịvairių pakopų besimokantysis iš įvairių Lietuvos universitetų. Besimokantieji - 18-30 metų, atitinkamai 27 moterys ir 4 vyrai, 27 bakalauro ir 2 magistro studentai. Du respondentai dèl tam tikru aplinkybių neatskleide duomenų apie turimą išsilavinimą.

Nauja informacija patenka per regejimą, kai 29\% žmonių išmoksta matydami (vaizdinè medžiaga). Klausydami (garsinė) išmoksta $34 \%$, o per judesị (vizualinė) išmoksta 37\% žmonių (Teresevičienè ir kt., 2004: 22). Tačiau tai negarantuoja, jog žmogus ịsimindamas medžiagą nenaudoja ir kitų informacijos pateikimo kanalų. Tai tik patvirtina, jog būtent per ši mokymosi kanalą patenka daugiausia informacijos. Remiantis gautais duomenimis, vaizdine informacija visiems ịsimenama geriausiai, tai ịrode didžioji dalis respondentų - 69\% (1 pav.). Mažesnę reikšmę ịsiminimui turi vizualinès (25\%) infor- 
macijos pateikimas, o garsinès medžiagos pateikimas padeda išmokti tik $6 \%$ respondentų. Todèl galime teigti, jog respondentai geriau ịsimena pateiktą informaciją mokymosi metu per vaizdą ir judesị (1 pav.).

Pasak Alfredo Bierarcho (2000: 12) savo kūno kalba žmogus teigiamai arba neigiamai veikia kitus, ir tai jis daro sąmoningai arba nesąmoningai. JAV profesorius Viljamas Kondonas teigia (Bierach, 2000: 17), jog kalbant žmogaus kūnas mažiausiais judesiais šoka pagal kalbos ritmą, todèl rankos, pirštai, galva, blakstienos ir t. t. juda kalbos ritmu. Su teiginiu, kad žymiai daugiau informacijos perduodama ne tik iš lūpų i lupas, bet ir kūnu, sutinka $87 \%$ respondentų ir tik $13 \%$ - ne (2 pav.).

Dellingas pažymi (Končiuvienè, 2005: 15), jog „distancinis švietimas - tai tokia mokymosi forma, kuomet besimokantieji yra fiziškai atskirti nuo mokytojų“. Mokymąsi auditorijoje galime traktuoti kaip visiškai priešingą mokymosi modelị virtualiajam, nes šiuo atveju mokymasis vyksta turint tiesioginị kontaktą tarp dėstytojo ir besimokančiojo, kai yra sukuriamos palankios sąlygos pastoviam bendravimui, diskutavimui ir pan. Būtent tokia mokymosi forma respondentams yra palankiausia mokymuisi, nes net $77 \%$ ( 1 pav.) teikia pirmenybę tokiam mokymuisi, o 23\% - virtualiam mokymuisi.

Mokymosi procese medžiagą galima pateikti ir tik ją nuskaityti, bet galima pateikti ir ją ịprasminti. Pasak Teresevičienès M. ir kt. (2004: 22), gerą pranešimą lemia vaizdinių priemonių panaudojimas, konkretus aiškinimas, sugebèjimas neviršyti laiko, judejjimas auditorijoje, balso tembras, nuolatinis kontaktas ir komunikacija su besimokančiaisiais, intrigos panaudojimas.

Tyrimo dalyvių atsakymai apie neverbalinès komunikacijos reikšmę atskleidžia jos svarbą. Net $94 \%$ respondentų kreipe dèmesị ị turinį ir jo pateikimą. (1 pav.).

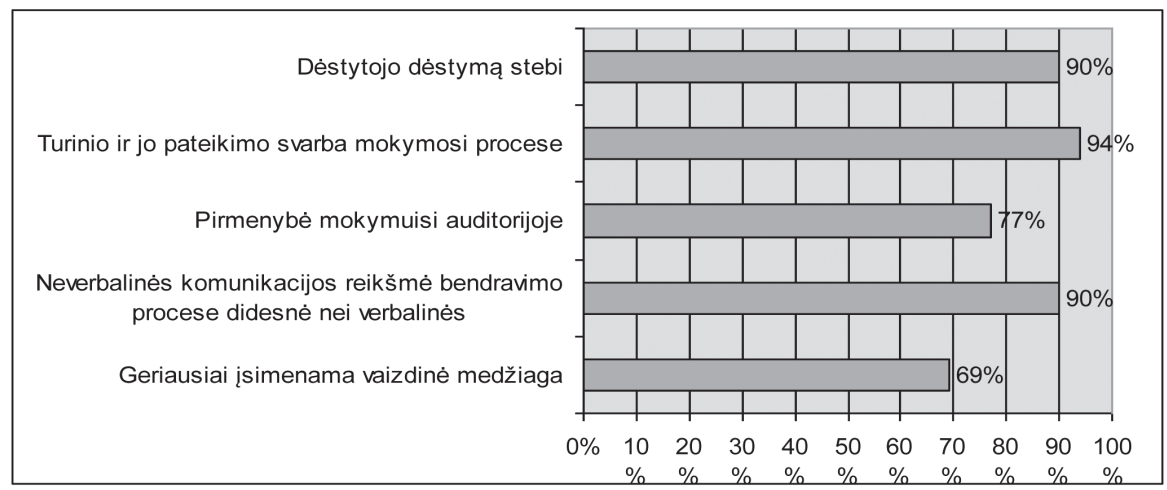

1 pav. Neverbalinè komunikacija mokymosi procese

Šaltinis: sudaryta autorès

Besimokantiesiems yra svarbu, kad dėstytojas medžiagą pateikia ją paịvairindamas tam tikrais gyvenimiškais pavydžiais bei juos iliustruoja gestais. Bet kokio pranešimo pa- 
pildymas gestais atneša sèkmę oratoriui, nei, priešingai, tik judinant lūpas. Būtent todèl yra svarbus ne statiškas, o pastoviai kintantis dèstytojo dèstymo vaizdas, kurị, pasirodo, stebi net $90 \%$ (1 pav.) respondentų. $74 \%$ respondentų sutiko, jog iš dèstymo procese raiškūs judesiai turi reikšmę ir tik 3\% nesutiko su šiuo teiginiu, o 23\% neturèjo nuomonès. Stebėti neverbalinę bendramokslių komunikaciją taip pat yra svarbu respondentams, kaip ir dėstytojų dėstymą ir tai patvirtino $90 \%$ respondentų (2 pav.). Galima daryti išvadą, jog neverbalinès komunikacijos svarba dominuoja tiek mokymosi procese, tiek ir už jo ribų, nes bendravimas su bendramoksliais gali vykti mokymosi proceso metu ir už jo ribų, ir tai gali turèti vienodą reikšmę.

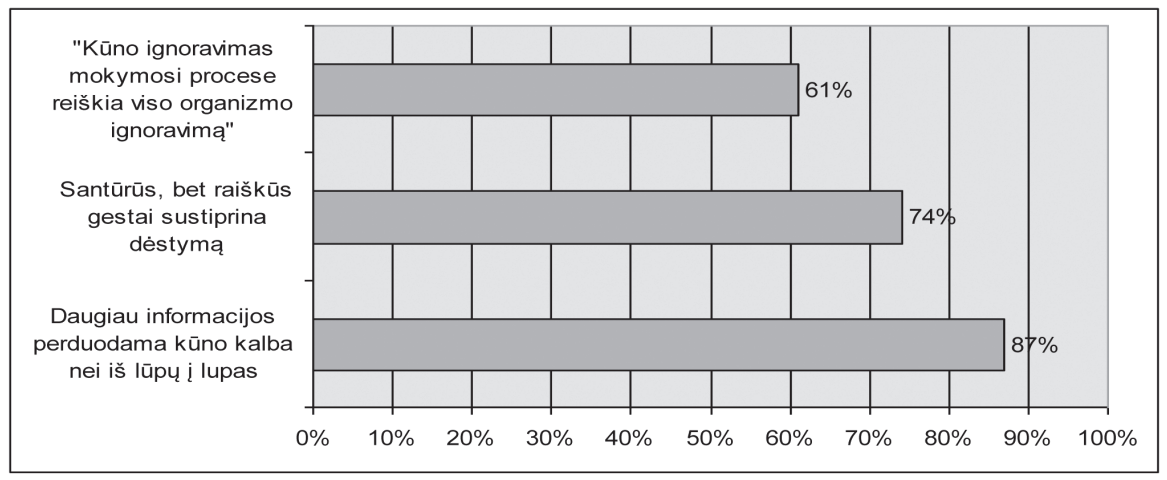

2 pav. Neverbalinè komunikacija dèstyme

Šaltinis: sudaryta autorès

Pasak K. Pukelio (1998: 211), mokytojams būtina žinoti visas komunikacines priemones, kurios gali būti naudingos perteikiant mokslo žinias, organizuojant pažintinę veiklą ir mokant dirbti savarankiškai. Psichologų pastebèta, kad kalbètojai, norintys įtikinti klausytojus, naudoja daug daugiau nežodinio bendravimo elementų, tarp jų daugiau gestų rankomis, galvos linktelejjimų, veido išraiškos aktyvumo (Bendravimo psichologija, 2001: 113). Todèl $74 \%$ respondentų sutiko, jog dèstymo procese raiškūs judesiai turi reikšmę ir tik 3\% nesutiko su šiuo teiginiu, o $23 \%$ neturëjo nuomonès (2 pav.).

Teigiama, kad kūno ignoravimas mokymosi procese reiškia ignoruoti visą organizmą, nes jis yra vientisas organų rinkinys, kurių funkcijos turi didelę reikšmę mokymosi procesui. $61 \%$ respondentų tuo abejoja, todèl sutiko tik iš dalies, o $16 \%$ iš viso nesutiko su šiuo teiginiu, bet $23 \%$ buvo tikri šio teiginio teisingumu ir jiems kūnas, neabejotina, mokymosi procese turi didelę reikšmę.

Apibendrinant galima teigti, jog kone visi suaugusieji, atsakydami ị klausimus patvirtino, kad neverbalinè komunikacija turi didesnę itaką, nei verbaliné komunikacija mokymosi procese. 


\section{Išvados:}

1. Neverbaliné komunikacija suprantama kaip sąmoningi ir nesąmoningi kūno judesiai ar kūno padètis, per kuriuos mes išreiškiame savo požiūrị ir jausmus.

2. Nors neverbalinė komunikacija traktuojama kaip savaime suprantamas reiškinys, visgi jos gilesniam supratimui įtakos turi kinestetika - studijos apie kūno kalbą ir jos raišką; proksemija, kuri nagrinejja žmogaus santykį su erdve; parakalba - studijos apie balso tonaciją.

3. Gauti empirinio tyrimo rezultatai patvirtino, kad neverbaline komunikacija perduodama daugiau informacijos, kuri yra geriau issimenama ir apdorojama, nei verbalinė komunikacija. Tai patvirtino atsakymai ị anketos klausimus, kurie atskleide, kad respondentams gestai, informacijos perdavimas kūnu sustiprina dèstymą. Tyrimas išryškino, kad mokymosi procese svarbi ne tik dėstytojo verbaliai ir neverbaliai pateikiama informacija, bet ir bendramoksliu neverbalinè reakcija ị dėstomą medžiagą.

\section{Literatūra}

Bendravimo psichologija.(2001) Kaunas: Technologija.

Bierach A. (2000) Kūno kalba. Kaunas: Tyrai. Cooper P. J., Calloway-Thomas, C., Simonds, C. J. (2007). Intercultural Communication: a Text with Readings. Pearson A and B: Boston, New York.

Ekman P. (2003). Unmasking the face. Printed in the United States of America.

Hall E.T. (1963). Proxemics - A Study of Man's Spatial Relationship. International Universities Press.

Jovaiša L. (1993). Pedagogikos terminai. Kaunas: Šviesa.
Končiuvienè D. (2005). Informacinių komunikacijos technologijų vaidmuo nuotolinio švietimo plètrai Panevèžio regione. Kaunas: KTU.

Matulienè G. (2007). Bendravimo psichologija. Žodinis bendravimas. Kaunas: Technologija. KTU Psichologijos katedra.

Pease A. (2003). Kūno kalba: kaip pagal gestus skaityti kitų žmonių mintis. Kaunas: Dajalita. P -7-19.

Pukelis K. (1998). Mokytojų rengimas. Kaunas. Teresevičienė, M., Oldroyd, D., Gedvilienè, G. (2004). Suaugusiujjų mokymasis. Kaunas: Vytauto Didžiojo universitetas. 


\title{
TRANSCULTURAL ASPECTS OF NON-VERBAL COMMUNICATION: IMPORTANCE OF NON-VERBAL COMMUNICATION IN A LEARNING PROCESS
}

\author{
Lina Nikitinaitè, Lietuva
}

Summary. Learning is a quite difficult process for learners, and no less difficult for the organizers of the learning process. Traditionally, more attention is paid just to words said to people who are willing to learn, with little attention to how the words are said. This article focuses on non-verbal communication, which is gives $93 \%$ of information in all life situations, the same as in the learning process, and is attendant of verbal communication, which gives $7 \%$ of information.

The research showed that non-verbal communication is very important for students in the learning process. More than $80 \%$ of respondents said that non-verbal communication is vital. In that case non-verbal communication has a much bigger impact in the behaving process, the same as in the learning process. Just very small percent of respondents pointed out that they preferred distance learning, which does not include non-verbal communication. Moreover, the biggest amount of respondents said that they used to give more information through body language than what is said through words. In summary, non-verbal communication should be viewed as important as verbal communication to make learning process more successful.

Key words: Non-verbal communication, body language, learning process, intercultural competence.

Lina Nikitinaitė, Mykolo Romerio universitetas, Edukologijos ir socialinio drabo institutas, doktorantè. Mokslinių interesų kryptys: švietimas, neverbalinė komunikacija mokymo/si procese.

Lina Nikitinaite, Mykolas Romeris University, Institute of Education Sciences and Social Work, Doctoral student. Research interests: education, non-verbal communication in learning and teaching processes. 